\title{
ARTIKEL
}

\section{THE EFFECT OF NUMBERED HEADS TOGETHER TECHNIQUE ON STUDENTS' ACHIEVEMENT IN READING RECOUNT TEXT}

\author{
Disusun dan Diajukan oleh:
}

\author{
Freddy Simarmata
}

NIM. 2101121021

\section{Telah diverifikasi dan dinyatakan memenuhi syarat} untuk diunggah pada jurnal online

\section{Medan, Agustus 2017}

\section{Menyetujui}

Dosen Pembimbing Skripsi

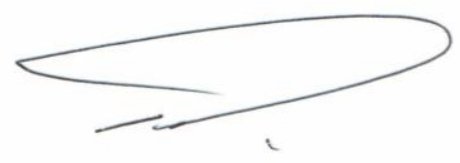

Dra. Masitowarni Siregar, M.Ed. NIP. 196711021993032001
Ka. Program Studi Pendidikan Bahasa Inggris

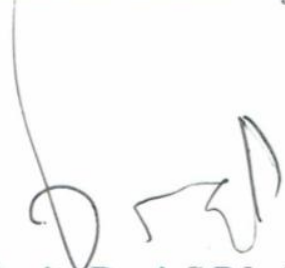

Nora Ronita Dewi, S.Pd., S.S., M.Hum. NIP. 198005222008122003 


\title{
THE EFFECT OF NUMBERED HEADS TOGETHER TECHNIQUE ON STUDENTS' ACHIEVEMENT IN READING RECOUNT TEXT
}

\author{
* Freddy Simarmata \\ * Masitowarni Siregar
}

\begin{abstract}
The objective of this study was to investigate whether Numbered Heads Together Technique significantly affected on students' achievement in reading recount text. This study was an experimental research design. The population of this study was grade X students of SMA Swasta Teladan Medan with the total number of students was 60 as samples and all of the students was taken by using random sampling. The students were divided into two groups, namely experimental and control group. The experimental group was taught by using Numbered Heads Together Technique, while the control group was taught by using Lecturing Method. The instrument of collecting data was multiple choice tests which then divided into pre-test and post-test. To obtain the result of the reliability of the test, the researcher used the Kuder Richardson formula (KR-21). The result of the calculation showed that the reliability of the test was 0.64, which means that the reliability of the test is high. The data were analyzed by using t-test formula. The result of the analysis showed that $t_{\text {value }}$ is higher than $t_{\text {table }}(5.50>$ 2.00 ) at the level of significance 0.05 with the degree of freedom (df) 58 . It means that there is a significant effect of using Numbered Heads Together Technique on the students' achievement in reading recount text.
\end{abstract}

Keyword: Numbered Heads Together Technique, Reading Achievement.

\section{Introduction}

\section{Background of Study}

Language is an instrument of communication. Humans deliver their ideas or judgements by language. The delivery of thought may be done through speaking or writing. The ideas that are delivered are received through listening or reading. Listening, speaking, reading and writing are called skills of language. Listening 
cannot be separated from speaking and reading cannot be separated from writing, because they support each other.

In foreign language learning, reading is the one of important skill to be taught to the students because through reading they will get information, knowledge and science. Grabe \& Stoller (2002:9) state that reading is the ability to draw meaning from the printed page and interpret the information appropriately.

Goodman (1976:497) state that reading is a selective process. it involves partial use of available minimal language cues selected from perceptual input on the basic of the readers' expectation. From the quotation above, reading means to find out the message or information that the writer put into the text as efficient as possible.

Harmer (2003:208) states that students sometimes have low expectation of reading. Reading passage is bound to be too difficult for them and they predict that the whole experience will be frustating and de-motivating. Such attitudes often due to unsucessful experience in reading. Consequently, students will need to read the text two or three times to get even an approximately sense. all this takes time and many less motivated students give up.

In this case, reader must be able to get the main idea from the text. Based on http//www.wikipedia.com/reader/factors, reading is a means of Language acquisition of communication, and of sharing information and ideas. Like all language, it is a complex interaction between the text and the reader which is shared by the readers' prior knowledge, experiences, attitude, and language 
community which is culturally and socially situated. The reading process requires continious practices, development, and refinement.

Further, in English curriculum, Education Unit-Oriented curriculum (Kurikulum Tingkat Satuan Pendidikan; KTSP) of Senior High School level states that there are four language skills that should be achieved in learning process namely, listening, speaking, reading and writing. Reading is one of the four skills that must be mastered. It is stated that students are intended to comprehend the text. In second year of Senior High School, the several kinds of texts genre are reports, narrative, analytical expositions.

Using the conventional method proved that students learn systematically, because education has emphasized the manipulation context in traditionaly where students have to memorize names, fact, figures, places, dates and events. They only study the subjective in isolation from one another and drill them in the roles of acquire basic writing and computing skill. The students were forced to concentrate on mastering content, not how to apply knowledge. Education nowadays tries to emphasize in learnign proces and it becomes the most important things use in getting knowledge. The knowledge received in students learning will be meaningful if it can be applied in group discussion. The emphasized of Numbered Head Together c lass extremely focus on the technique. To prove the validity of the Numbered Head Together technique used, the research should be made applying the tecnique in the classroom. It is expected that numbered head together will affective in teaching reading achievement. 
Based on background above, the writer design to conduct out this research to prove whether applying numbered head together technique can significantly affect on students' reading achievement.

\section{Research Question}

In line with the background of study, the problem of this study is formulatedas follows: "Is there any significant effect of applying Numbered Heads Together Technique on students' achievement in reading recount text?”

\section{Conceptual Framework}

Reading comprehension is the process of cunstructing meaning by coordinating a number of complex processes that include word reading, word and word knowledge, and fluency (Klingner and Vaughn 2007:2-3) . Comprehension itself means the building of meaning from those sounds such as from speakers, reading a text, gestures, etc. In the reading comprehension, involve construction process. When someone tries to comprehend words from text, he is involved in a mental process. The process is called a construction process. The construction process starts from recognizing words, identifying words to build meanings and comprehension. Although there is little question that difficulty in these foundational skills impede successful growth in reading for many students, it is also true that many students with learning disabilities have significant challenges understanding and learning from text even they are able to decode adequately. Our knowledge and experiences related to the key ideas in the text we read, influence

what we learn and remember about what we read. Word knowledge and word meaning influence our understanding. 
Numbered Heads Together Technique is an excellent structure for combining learning partnerships into groups or teams of four. According to Kagan (2009), Numbered Heads Together Technique is a learning method when each students are given a number and they make a group of work and then the teacher will call the number of the students randomly. The purpose of this technique is the students are able to process the information. They also can develop their thinking, review material, and check their prior knowledge. Numbered Heads Together (NHT) can serve any activities in the classroom. It means that there are many other ways for ensuring the teacher cues the students into collaborative activity. The students work together and they quiet literally 'put their heads together' in order to solve problem and also ensure that everyone in the group can answer the question.

The teacher, in this case, asks an answer by calling the number and the students with number called then take their turns to answer. If there are not enough students ready to respond to the techer may judge that a little more time. Answer can be taken in number of choices: 1) select one student, 2) select one but ask others to colaborate or comment, 3) ask different students to give a particular part of the answer.

\section{Methodology}

This study was conducted by applying experimental research. An experimental research using two groups of sample namely experimental group and control group was applied. The experimental group was taught by using Numbered Heads Together Technique, while the control group was taught by using conventional technique. Clearly, the research design is figured in Table 3.1. 
Table 3.1 Research Design

\begin{tabular}{|l|c|l|c|}
\hline Group & Pre-Test & Treatment & Post-Test \\
\hline Experimental & $\sqrt{ }$ & Numbered Heads Together Technique & $\sqrt{ }$ \\
\hline Control & $\sqrt{ }$ & Lecturing Method & $\sqrt{ }$ \\
\hline
\end{tabular}

The population of this research is the students of the grade $\mathrm{X}$ of SMA Swasta Teladan Medan. There are 5 classes of grade X. Each class consisted of 30 students. In selecting the sample, random sampling by using lottery was applied; the first class which is taken from the lottery was the experimental group. The second class was the control group.

\section{Technique for Analyzing the Data}

To analyze the data in order to find out the difference means of scores of both experimental and control group, t-test will be applied.

$$
t=\frac{M a-M b}{\sqrt{\left(\frac{d a^{2}-d b^{2}}{N a-N b-2)\left(\frac{1}{N a}-\frac{1}{N b}\right)}\right.}}
$$

Notes :

$M a$ : the mean of experimental group

$M b$ : the mean of control group

$d a \quad$ : the standard deviation of experimental group

$d b \quad$ : the standard deviation of control group

$\mathrm{Na}$ : the total sample of experimental group

$\mathrm{Nb}:$ the total sample of control group 


\section{Result and Discussion}

In order to find out whether the application of Numbered Heads Together Technique had a significant effect on students' reading comprehension, the result of the test was calculated by using t-test formula as in following:

$$
\begin{aligned}
& t=\frac{M a-M b}{\sqrt{\left[\frac{d a^{2}+d b^{2}}{n a+n b-2}\right]\left[\frac{1}{n a}+\frac{1}{n b}\right]}} \\
& t=\frac{25.73-17.46}{\sqrt{\left[\frac{1301.90+911.60}{(30+30)-2}\right]\left[\frac{1}{30}+\frac{1}{30}\right]}} \\
& t=\frac{\sqrt{8.27}}{\sqrt{\left[\frac{2213.5}{58}\right]\left[\frac{2}{30}\right]}} \\
& t=\frac{8.27}{\sqrt{[38.16][0.06]}} \\
& t=\frac{8.27}{\sqrt{2.28}} \\
& t=\frac{8.27}{1.56} \\
& t=5.50
\end{aligned}
$$

The calculation shows the statistic data of both experimental and control group in pre-test and post-test. The result shows that t-observed is higher than t-table in which $5.50>2.00$ with $\mathrm{p}=0.05$ and the degree of freedom $(\mathrm{df})=$ 58. It means that Numbered Heads Together Technique had significant effect on students' achievement in reading recount text.

The result of this research shows that there is difference of output between both classes. For the product data, based on the statistical calculation, it was obtained that t-observed (5.50) is higher than t-table (2.00) for the degree of 
freedom (df) 58 at level of significance 0.05 . It means that the alternative hypothesis (Ha), which is there was significant effect of applying Numbered Heads Together Technique on students' achievement in reading recount text, is accepted. For the process data, it can be seen that the students which were taught by using Numbered Heads Together Technique got better achievement than students which were not taught by using Numbered Heads Together (taught by using Lecturing Method).

According to Trianto (2002:38), Numbered Heads Together technique has some advantages, they are:

1) It is considered to help the students to give the solution to each question or problem.

2) All of the students can do the discussion intensively and give their idea, feelings, and thought without any authorities from others.

3) It gives the possibility to the students to know his progress based on his ability.

4) The students with better knowledge can teach and coach others to find the solution.

5) The students become more actively involved in the learning process.

6) This technique focused on the learner-centered in which between students work in group and teacher participate each other to solve the problem.

7) The teacher feels more free in the instructional process. 


\section{Conclusion and Suggestions}

\section{Conclusion}

After analyzing the data, it was found that the scores of the students that were taught by applying Numbered Heads Together Technique was higher than those who were taught without applying Numbered Heads Together Technique.

The alternative hypothesis (Ha) was accepted which means that there was significant effect of applying Numbered Heads Together Technique on students' achievement in reading descriptive text. Besides that, the students' attitude and skill was also significantly improved from the first until the third meeting while being taught by using Numbered Heads Together Technique. It implies that Numbered Heads Together Technique is a significant technique for teaching reading recount text.

\section{Suggestion}

Based on the conclusion drawn, the results of the findings contribute some valuable suggestions, they are:

1. The English teachers are suggested to use Numbered Heads Together Technique to improve students' achievement in reading recount text and also to improve their attitude and skill during the teaching and learning process because this technique can motivate the students to read better and share their ideas with their group members.

2. The students are suggested to apply Numbered Heads Together Technique to improve their reading comprehension ability, attitude and skill because it can stimulate them to share their ideas and be responsible with their tasks and their group members. 
3. The other researchers, who want to study more about Numbered Heads Together Technique, this research could be advisable reference for conducting similar language skills, reading, with different genre. 


\section{References}

Arikunto, Suharsimi. 2006 . Prosedur Penelitian : Suatu Pendekatan Praktik. Jakarta : Rineka Cipta.

Brown, H. D. 2004. Language Assessment Principles and Classroom Practices. New York : Longman Group.

Grabe, William and Fredrika L. Stoller. 2002. Teaching and Researching Reading. Harlow : Pearson Education Ltd.

Kagan, Spencer. 2009. Kagan Cooperative Learning. San Clemente. CA : Kagan Publishing.

Kementrian Pendidikan dan Kebudayaan. 2014. Materi Pelatihan Guru Implementasi Kurikulum 2013 Tahun 2014 : Materi Pelajaran Bahasa Inggris SMA/SMK - Untuk Guru. Badan Pengembangan Sumber Daya Manusia Pendidikan dan Kebudayaan dan Penjaminan Mutu Pendidikan.

Klingner, Janette K and Sharon Vaughn. 2007. Teaching Reading Comprehension to Students with Learning Difficulties. New York: The Guildford Press.

Knapp and Watkins. 2005. Genre, Text, Grammar: Technologies for Teaching and Assessing Writing. Sydney: University of New South Wales Press.

Lie, Anita. 2007. Cooperative Learning: Mempraktekkan Cooperative Learning di Ruang Kelas. Jakarta: Grasindo.

Nuruddin, I.K. Seken and L.P. Artini. 2013. The Effect of Numbered Heads Together and Question Answer Relationship Techniques on Students' Reading Comprehension : A Comparative Study. Jurnal Program Pascasarjana Universitas Pendidikan Ganesha Vol 1 Tahun 2013. Singaraja : Universitas Pendidikan Ganesha.

Pardiyono. 2006. 12 Writing Clues for Better Writing Competence. Yogyakarta: Penerbit Andi.

Satria, Supriadi, Rismaya Marbun and Stevanus Buan. 2013. Students' Improvement in Reading Comprehension on Recount Text Through Numbered Heads Together. A thesis. Languages and Arts Education Department. Faculty of Teacher Training Education. University of Tanjung Pura.

Siahaan, S. \& Shinoda, K. 2008. Generic text Structure. Yogyakarta: Graha Ilmu 